\title{
AN EVALUATION OF ENDOPROSTHESIS AND PERTROCHANTERIC EXTERNAL FIXATOR RESULTS IN ELDERLY INTERTROCHANTERIC FEMORAL FRACTURES
}

\author{
Aydin Ekrem, ${ }^{1}$ Ates $\mathrm{Ali}^{2}$ \\ ${ }^{1}$ Anadolu Hospital Orthopedic and Traumatologia clinic, Bursa, Turkey \\ ${ }^{2}$ Karaman State Hospital Orthopedic and Traumatologia clinic, Karaman, Turkey
}

Primljen/Received 06. 09. 2019. god.

Abstract: Objective: In this study, 14-month clinical outcomes of the endoprosthesis and pertrochanteric external fixator application are retrospectively evaluated in elderly patients with pertrochanteric fractures.

Patients and Method: A total of 45 patients of 65 years old and older (25 females and 20 males) with a mean age of 78.1, who were treated due to intertrochanteric femur fracture between November 2013 and December 2014 and whose controls could be made were included in this study. The deaths that occurred within the postoperative 1 year were not included in the study. 28 patients with endoprosthesis as Group I, and 17 patients with pertrochanteric external fixator as Group II were evaluated.

Results: Table 2 shows the clinical evaluation results of the patients according to different criteria by the groups. The mean operation time was $45 \mathrm{~min}$ in Group I and 20 min in Group II. The external fixator application time is significantly shorter. The mean hospital stay was 14 days for Group I and 10 days for Group II. The hospital stay period of the external fixator group is 4 days shorter.

While 7 patients were taken into the intensive care unit in Group I postoperatively, only 1 patient was taken into the same unit in Group II. This difference was significantly in favor of the external fixator group.

While 14 patients in Group I needed a preoperative and postoperative blood transfusion, no patient needed blood transfusions in Group II. External fixator application is significantly more advantageous in terms of patient hemodynamics.

The mean time to postoperatively move the extremity independently in the bed was 24 hours in Group I and 36 hours in Group II.

All patients were exposed to the Harris hip scoring in the postoperative 12 . month (the fixator was removed for the external fixator group).
Prihvaćen/Accepted 26. 11. 2019. god.

Conclusion: In addition to internal fixation options and endoprosthesis applications in elderly intertrochanteric femoral fractures, an external fixator may also be a good treatment alternative with appropriate patient selection and proper application in accordance with the technique thanks to its short surgical time, less blood loss and easy applicability.

Key words: Elderly patient, proximal femoral fracture.

\section{INTRODUCTION}

Intertrochanteric femoral fractures are among the most important fractures that orthopedic surgery encounters frequently, especially in elderly patients (1). The choice of treatment method is challenging for the orthopedist since the bone quality of these patients is low, several elderly diseases that disrupt the general condition of the patient accompany the disease and there is the necessity of treating the fracture as soon as possible (2).

The main aim of the treatment of fractures in this region is to obtain a rigid bone fixation and a mobile hip joint (3). Intramedullary nails, plates, and screws of various types and features, hip prostheses and external fixators are among the treatment options. In these treatment methods, shortness, abductor-adductor, and flexor deficiencies, union, and stabilization problems are the conditions that make the choice of treatment difficult $(2,4-11)$.

In this study, 14-month clinical outcomes of the endoprosthesis and pertrochanteric external fixator application are retrospectively evaluated in elderly patients with pertrochanteric fractures in two groups.

\section{PATIENTS AND METHODS}

A total of 45 patients of 65 years old and older ( 25 females and 20 males) with a mean age of 78.1, who 
Table 1. Distribution of Ewans fracture types according to the Groups

\begin{tabular}{|c|c|c|}
\hline $\begin{array}{c}\text { Fracture Type } \\
\text { (Modified Ewans) }\end{array}$ & $\begin{array}{c}\text { Group I } \\
\text { (Mean age: } \mathbf{7 9 . 6}) \mathbf{n}=\mathbf{2 8}\end{array}$ & $\begin{array}{c}\text { Group II } \\
\text { (Mean age: 75.1) } \mathbf{n}=\mathbf{1 7}\end{array}$ \\
\hline Type I & 13 & 7 \\
\hline Type II & 10 & 3 \\
\hline Type III & 3 & 3 \\
\hline Type IV & 2 & 0 \\
\hline Type V & 0 & 0 \\
\hline Type R & 0 & 4 \\
\hline
\end{tabular}

were treated due to intertrochanteric femur fracture between November 2013 and December 2014 and whose controls could be made were included in this study. The deaths that occurred within the postoperative 1 year were not included in the study.

Twenty-eight patients with endoprosthesis were evaluated as Group I, and 17 patients with pertrochanteric external fixator as Group II. The fracture types of the patients according to the Modified Ewans (Kyle) classification (12) are shown in Table 1.
Group I patients underwent calcar-assisted bipolar endoprosthesis with spinal anesthesia by three different orthopedic surgeons at the Orthopedics and Traumatology Clinic of Ministry of Health Evliya Celebi Training and Research Hospital affiliated to DPU. Group II patients underwent pertrochanteric external fixator with spinal anesthesia and scope control by the same orthopedic surgeons in the same clinic.

The mean follow-up period was 13.6 months for Group I patients and 14.3 months for Group II patients.

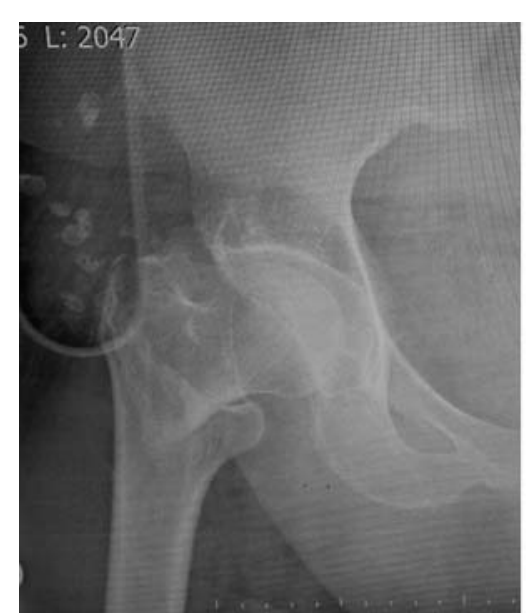

Figure 1: $76 y$

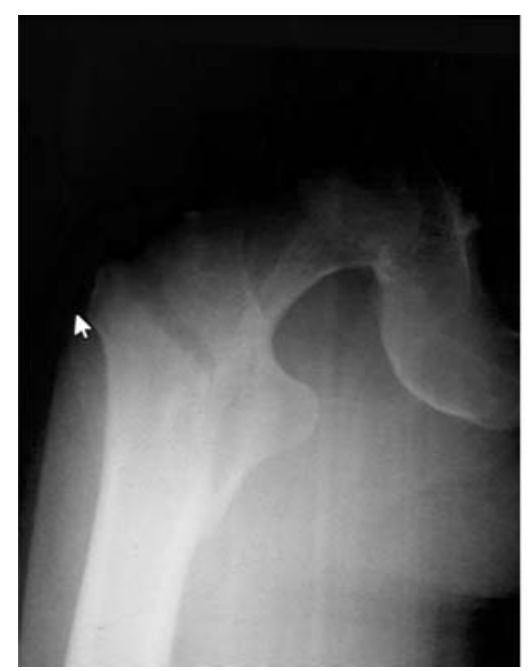

Figure 4. $70 y \mathrm{~m}$

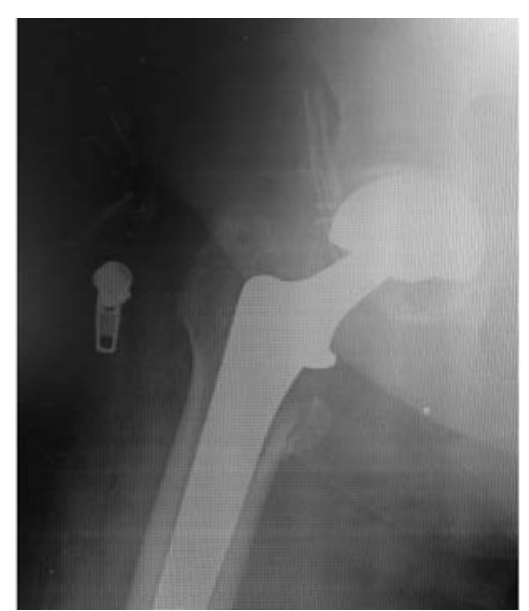

Figure 2. Postop. 3rd day

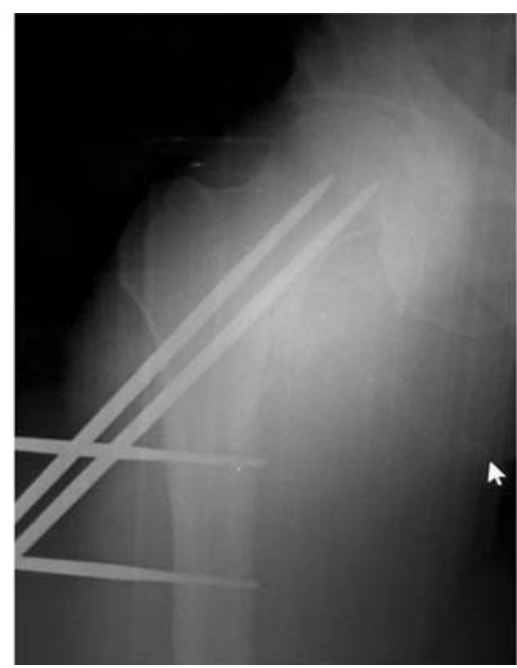

Figure 5. Postop 3rd day

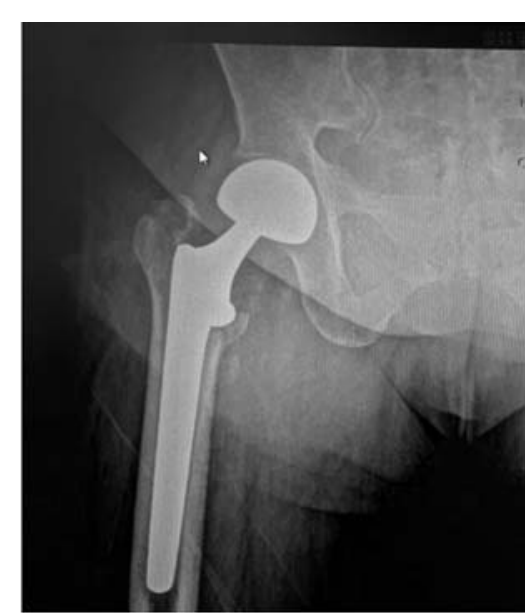

Figure 3. Postop 3rd month

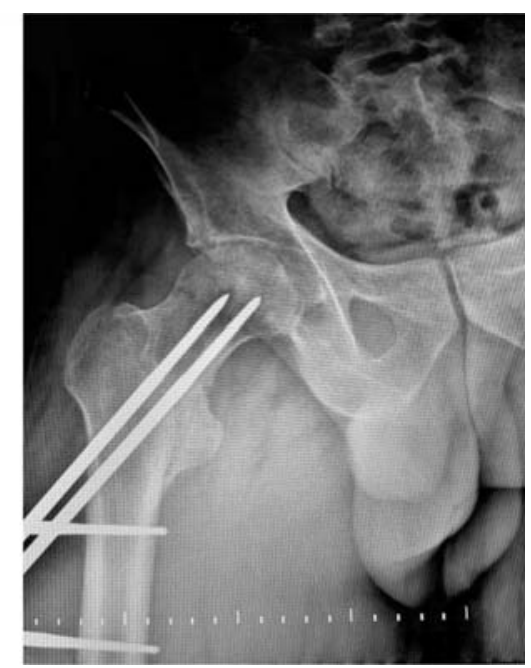

Figure 6. Postop 4th month 
The fixators were removed in a mean of 7.3 months (4-10 months). The patients who died within the postoperative 1 year were not included in the study. Statistical analyses were performed by the $\mathrm{U}$ test at $\mathrm{P}<0.05$ significance level.

The two groups were compared in terms of the mean operation time, length of hospital stay, number of patients requiring intraoperative or postoperative blood transfusion, number of patients taken into postoperative intensive care unit, postoperative time to move the extremity independently in the bed, meantime of walking with walker assistance, mean full weight-bearing time, and number of patients who developed early complications in the first trimester postoperatively.

X-rays of exemplary cases are shown below (Figures 1-6).

\section{RESULTS}

Table 2 shows the clinical evaluation results of the patients according to different criteria by the groups.

The mean hospital stay was 14 days for Group I and 10 days for Group II. The hospital stay period of the external fixator group is 4 days shorter.

While 7 patients were taken into the intensive care unit in Group I postoperatively, only 1 patient was taken into the same unit in Group II. This difference was significantly in favor of the external fixator group.

While 14 patients in Group I needed a preoperative and postoperative blood transfusion, no patient nee- ded blood transfusions in Group II. External fixator application is significantly more advantageous in terms of patient hemodynamics.

The mean time to postoperatively move the extremity independently in the bed was 24 hours in Group I and 36 hours in Group II. Although these values were not found to be statistically significant, our clinical observations suggest that patients with external fixators.

The mean time to stand up with postoperative help and support was found to be 48 hours in both groups, thus, no difference was observed between the groups in this respect.

The average time to postoperatively start to bear full weight to the extremity and walk in short distance without the assistance of others was 30 days for Group I and 45 days for Group II. This difference is significantly in favor of the endoprosthesis application.

In Group I, one or multiple of such complications as prosthesis dislocation, early loosening, protrusion, and infection were observed in 4 patients within the postoperative early trimester period, whereas in Group II, one or multiple of such early complications as nail protrusion, reduction loss, and infection were seen in 3 patients; therefore, no significant difference was found between the two groups in terms of early complications.

All patients were exposed to the Harris hip scoring in the postoperative 12. month (the fixator was removed for the external fixator group) and the results are shown in Table 3.

Table 2. Clinical results

\begin{tabular}{|l|c|c|c|}
\hline \multicolumn{1}{|c|}{ Parameter } & Group I & Group II & p \\
\hline Average operation time & 45 min & 20 min & $\mathrm{P}<0.05$ \\
\hline Mean total length of hospital stay & 14 days & 10 days & $\mathrm{P}<0.05$ \\
\hline Number of patients requiring a blood transfusion & 14 patients & - & $\mathrm{P}<0.05$ \\
\hline Number of patients taken in the postoperative intensive care unit & 7 patients & 2 patients & $\mathrm{P}<0.05$ \\
\hline Mean time to postop move the extremity independently & 36 hours & 24 hours & $0.05<\mathrm{p}<0.10$ \\
\hline Meantime to walk with help and walker & 48 hours & 48 hours & $\mathrm{P}<0.05$ \\
\hline Mean full weight-bearing time & 30 days & 45 days & $\mathrm{P}<0.05$ \\
\hline $\begin{array}{l}\text { Number of patients developing early postoperative } \\
\text { complications }\left({ }^{*}\right) \text { in the first trimester }\end{array}$ & 4 patients & 3 patients & $\mathrm{p}>0.05$ \\
\hline
\end{tabular}

(*) For Group I; Loss of reduction, Nail protrusion, Nail bed infection

For Group II; Dislocation, infection, early prosthesis loosening

Table 3. Harris Hip Score table in the postop 12th month

\begin{tabular}{|l|c|c|c|}
\hline & Group I & Group II & p \\
\hline$<70$ (Poor) & 7 & 4 & $\mathrm{p}>0.05$ \\
\hline $70-79$ (Fair) & 15 & 7 & $\mathrm{p}>0.05$ \\
\hline $80-89$ (Good) & 6 & 4 & $\mathrm{p}>0.05$ \\
\hline $90-100$ (Excellent) & - & 2 & - \\
\hline
\end{tabular}


No significant difference was found between the two groups in terms of poor, fair and good results. No good results were seen in the patients in group I, while 2 patients in group II demonstrated good results.

\section{DISCUSSION}

Hip fractures can cause many serious complications and even death as they make the patient bed-dependent. Therefore, it is of crucial importance to mobilize the elderly as soon as possible, in order to prevent probable complications arising from bed-dependence and to return the elderly to pre-fracture activity as much as possible. Fracture structure and type are as important as the general condition of the patient in choosing the treatment type $(5,6,7,8)$.

Although the endoprosthesis application seems to be advantageous in terms of early mobilization because it allows early weight-bearing, early mobilization and weight-bearing are also possible in external fixator applications when adequate reduction and stabilization is achieved $(9,12)$. In our study, there was not much difference in terms of stand up and weight-bearing performances of the two applications.

As in our study, postop mobilization may be delayed due to higher blood loss in endoprosthesis surgeries when compared to external fixator surgeries and to further deterioration of hemodynamic balance (13).

In cases where bone quality is thought to be insufficient, it is recommended to place three shank nails proximally and distally to prevent reduction insufficiency (14).

The incidence of nail bed infection in the treatment of pertrochanteric fractures with external fixator is variable, and rates up to $30 \%$ have been reported $(9$, $14,15,16)$. In our study, severe nail bed infection was seen in 2 cases (11.7\%) but this was regressed through frequent dressing and nail bed care, and bone infection did not develop.

One of the most obvious causes of nail bed infection is tension in the tissues and skin and soft tissue damage due to improper placement of the Schanz nails and disruption of circulation in this region (17).

It is reported that the most common causes of infections seen in orthopedic surgery are prolonged operation times and tissue damage (18). Endoprosthesis op- erations are significantly longer and more traumatic than external fixator applications. The use of external fixators in hip fractures, which began to be used in the 1950 s, is easy to apply and its duration is short. However, it is not recommended in extreme osteoporotic bones since insufficiencies may develop $(9,17,18)$. Perprosthetic fractures are also frequently seen in excessive osteoporotic bones (19).

During the medullar cavity and insertion of the prosthesis in endoprosthesis surgery, coercion of the hip with excessive external rotation and adduction in lateral intervention and its coercion to excessive internal rotation in posterolateral procedure increases the risk of micro embolism (20).

In the application of external fixator, less microembolism and vascular system coercion occur due to the fact that the patient and the extremity is not given a coercive position and the medullary cavity is not performed.

Also in external fixator application, the fact that the patient's own bone tissue and hip joint are protected provides the opportunity to shift to endoprosthesis when necessary.

\section{CONCLUSION}

In addition to internal fixation options and endoprosthesis applications in elderly intertrochanteric femoral fractures, an external fixator may also be a good treatment alternative with appropriate patient selection and proper application in accordance with the technique thanks to its short surgical time, less blood loss and easy applicability.

\section{Abbreviations \\ DPÜ: Dumlupınar University}

Conflict of Interests: The authors declare that there are no conflicts of interest related to this article.

Funding: None

\section{Licensing}

This work is licensed under a Creative Commons Attribution 4.0 International (CC BY 4.0) License. 


\title{
Sažetak
}

\section{EVALUACIJA REZULTATA UGRADNJE ENDOPROTEZE I PERTROHANTERNOG SPOLJAŠNJEG FIKSATORA KOD INTERTROHANTERNOG PRELOMA FEMURA KOD STARIJIH PACIJENATA}

\author{
Aydin Ekrem, ${ }^{1}$ Ates $\mathrm{Ali}^{2}$ \\ ${ }^{1}$ Anadolu Hospital Orthopedic and Traumatologia clinic, Bursa, Turkey \\ ${ }^{2}$ Karaman State Hospital Orthopedic and Traumatologia clinic, Karaman, Turkey
}

Cilj: U ovoj studiji, retrospektivno je analiziran 14-mesečni klinički ishod primene endoproteze i pertrohanternog spoljašnjeg fiksatora, kod starijih pacijenata sa pertrohanternim prelomima.

Pacijenti i metode: U studiju je uključeno ukupno 45 pacijenata starosti preko 65 godina ( 25 žena i 20 muškaraca), prosečne starosti od 78,1 godinu, koji su mogli biti praćeni na redovnim postoperativnim kontrolama, a koji su lečeni zbog intertrohanternog preloma butne kosti, između novembra 2013. i decembra 2014. godine. Smrtni slučajevi koji su se dogodili u toku postoperativne godine nisu uključeni u studiju.

Evaluirani su pacijenti podeljeni $u$ dve grupe i to: 28 pacijenata sa endoprotezom koji su predstavljali grupu I, a 17 pacijenata sa pertrohanternim spoljnim fiksatorom, grupu II.

Rezultati: Tabela 2 pokazuje rezultate kliničke evaluacije pacijenata prema različitim kriterijumima po grupama. Srednje vreme trajanja operacije bilo je 45 minuta u Grupi I i 20 minuta u Grupi II. Vreme aplikacije spoljnjeg fiksatora je znatno kraće. Prosečan boravak u bolnici za grupu I bio je 14 dana, a za Grupu II 10 dana. Period boravka u bolnici za grupu sa spoljnim fiksatorima je 4 dana kraći.

\section{REFERENCES}

1. Olson SA, Schemitsch G, Morwood M, Schemitsch E, Russell TA., Latta LL. Hot topics in biomechanics: hip fracture fixation. J Orthop Trauma. 2015; 29(suppl 12): S1-5.

2. Russell TA, Browne TD, Jacofsky M, Chang J, Angle SR, YetkinleD et al. The problem of fracture fixation augmentation and description of a novel technique and implant for femoral neck stabilization. Techniques in Orthopaedics. 2015; 30(1): 22-7.

3. Srinivas K, Raghunandan G, Ramana Y, Rajaiah D, Kumar PK, Omkaram S et al. A study on surgical management of intertrochanteric and subtrochanteric fractures of femur by proximal femoral nail. Journal of Evidence-based Medicine and Healthcare. 2015; 2(3): 228-35.

4. Sharma H, Loomba DS. Comparison of outcome of management of unstable pertrochanteric femoral fractures with dynamic hip screw and proximal femoral nail. African Journal of Trauma. 2015; 4(1): 21.

5. Aydın E, Dulgeroglu TC, Metineren H.Bilateral simultaneous intertrochanteric fractures of femur without major trauma. Int Med Case Rep J. 2015; 8: 137-9.
Dok je 7 pacijenata iz Grupe I postoperativno lečeno na odeljenju intenzivne nege, samo 1 pacijent iz Grupe II je lečen na ovom odeljenju. Ova razlika ide značajno u korist grupe sa spoljnim fiksatorima. Preoperativnu i postoperativnu transfuziju krvi je trebalo 14 pacijenata iz Grupe I, dok nikome iz Grupe II nije bila potrebna transfuzija. Primena spoljnog fiksatora je značajno povoljnija u pogledu hemodinamike pacijenta.

Srednje vreme za pomeranje ekstremiteta u krevetu bilo je 24 sata u Grupi I, a 36 sati u grupi II. Svi pacijenti su bili evaluirani prema Harisovom skoring sistemu u postoperativnom 12.mesecu (fiksator je uklonjen za grupu spoljnih fiksatora).

Zaključak: Pored opcija za unutrašnju fiksaciju i aplikacije endoproteze kod starijih pacijenata sa intertrohanteričnim frakturama femura, spoljni fiksator takođe može biti dobra alternativa lečenju uz odgovarajući odabir pacijenata i pravilnu primenu u skladu s tehnikom zahvaljujući kratkom vremenu operacije, manjem gubitku krvi i jednostavnoj primenjivosti.

Ključne reči: stariji pacijenti, fraktura proksimalnog femura.

6. Bridle SH, Patel AD, Bircher M, Calvert PT.Fixation of intertrochanteric fractures of the femur. A randomized prospective comparison of the gamma nail and the dynamic hip screw. J Bone Joint Surg Br.1991; 73(2): 330-4.

7. Gupta SV, Valisetti VS.Comparative study between dynamic hip screw vs proximal femoral nailing in inter-trochanteric fractures of the femur in adults. Int. J. Orthod. Sci. 2015; 1(1): 7-11.

8. Kazemian GH, Manafi AR, Najafi F, Najafi MA. Treatment of intertrochanteric fractures in elderly high-risk patients: Dynamic hip screw vs. external fixation. Injury. 2014; 45(3): 568-72.

9. Ozkaya U, Parmaksızoglu AS, Gul M, Kabukcuoglu Y, Ozkazanlı G, Basılgan S. Osteoporotik yaslı hastalarda pertrokanterik kırıkların eksternal fiksasyonla tedavisi. Acta Orthop Traumatol Turc. 2008; 42(4): 246-51.

10. Von Roth P, Abdel MP, Harmsen WS, Berry DJ. Cemented bipolar hemiarthroplasty provides definitive treatment for femoral neck fractures at 20 years and beyond. Clin Ortho Relat Res. 2015; 473(11): 3595-9. 
11. Kyle RF, Gustilo RB, Premer RF. Analysis of six hundred and twenty-two intertrochanteric hip fractures. Orthopedic Trauma Directions. 2007; 5(1): 29-31.

12. Inal S, Taspinar F, Gulbandilar E, Gok K.Comparison of the biomechanical effects of pertrochanteric fixator and dynamic hip screw on an intertrochanteric femoral fracture using the finite element method. The International Journal of Medical Robotics and Computer Assisted Surgery. 2015; 11(1): 95-103.

13. Kesmezacar H, Ogut T, Bilgili MG, Gokay S, Tenekecioglu Y. Ya 12 larda intertrokanterikfemur k2r2klar2n2n tedavisi: anternal tespit mi, hemiartroplasti mi. Acta OrthopTraumatol Turc. 2005; 39(4): 287-94.

14. Edipoglu E, Bilgili MG, Sar2 C, Basaran SH, Kural C, Avkan MC. Geriatrik hastalardaki intertrokanterik femur k2r2klar2n2n eksternal fiksatorle tedavisi. Med J Bakirkoy 2013; 9(1): 28-32.

15. Vossinakis IC, Badras LS. The external fixator compared with the sliding hip screw for pertrochanteric fractures of the femur. Bone Joint J.2002; 84(1): 23-9.
16. Moroni A, Faldini C, Pegreffi F, Hoang-Kim A, Vannini F, Giannini S. Dynamic hip screw compared with external fixation for treatment of osteoporotic pertrochanteric fractures. J Bone Joint Surg Am. 2005; 87(4): 753-9.

17. Ferreira N, Marais LC. Prevention and management of external fixator pin track sepsis. StrategiesTrauma Limb Reconstr. 2012; 7(2): 67-72.

18. Leaper D, Ousey K. Evidence update on prevention of surgical site infection. Curr Opin Infect Dis. 2015; 28(2): 158-63.

19. Ciortea V, Irsay L, Borda IM, Onac I, Ungur R. Correlation of periprosthetic bone mineral density and skeletal bone mineral density values in patients with total hip arthroplasty. Palestrica of the Third Millennium Civilization\&Sport. 2014; 15(1): 11-5.

20. Zhao J, Zhang J, Ji X, Li X, Qian Q, Xu Q. Does intramedullary canal irrigation reduce fat emboli? A randomized clinical trial with transesophageal echocardiography. The Journal of arthroplasty. 2015; 30(3), 451-5.

\section{Correspondence to/Autor za korespondenciju}

Ekrem Aydın

Address: Ertuğrulmah. Uğurmumcubulvar1, Biaportsitesi, no; 22 Nilüfer

05052155351,

Bursa/Turkey

email: efaruk92@gmail.com 